\title{
Effectiveness of Inquiry Learning Model on Critical Thinking Skills of Class IV Students in Natural Sciences Alternative Energy Material in Elementary School
}

\author{
A. Indra Nihlah Annashih* \\ Post Graduate, Universitas Negeri Surabaya \\ Prof. Dr. dr. Tjandra Kirana, M.S., Sp.And. \\ Lecturer, Universitas Negeri Surabaya \\ Dr. Raharjo, M.Si. \\ Lecturer, Universitas Negeri Surabaya
}

\begin{abstract}
The research is financed by Asian Development Bank. No. 2006-A171(Sponsoring information)
\section{Abstract}

The purpose of this study was to find out 1. Knowing students' critical thinking skills using the fourth grade inquiry learning model of elementary school. 2. To find out the activities of students in the learning process by using the fourth grade inquiry learning model of elementary school. 3. To find out the response of students by using the fourth grade inquiry learning model of elementary school. The method and design in this study were pre-experimental desings and one group pretest posttest desings. The results showed that the signifikan inquiry learning was significantly effective in increasing students' critical thinking skills. This is evidenced by the results of the t-test obtained by tcount (8.525) $>\mathrm{t}$ table $(2.056)$ and the average value of students' critical thinking tests increased from the average value of pretest 61.3 after receiving treatment posttest 77 average value, 73 . The inquiry learning model also makes students active. Using the inquiry model students respond well. This is evidenced by the response sheet of students who get a percentage of $83.9 \%$. In the learning process using inquiry learning models are categorized very well in the implementation of natural sciences learning alternative energy materials and make critical thinking students get a percentage of $100 \%$ while the value of achievement generated from learning uses the inquiry model that is 96,739 .
\end{abstract}

Keywords: models of inquiry learning, critical thinking, effectiveness.

DOI: $10.7176 /$ RHSS/9-11-05

Publication date:June $30^{\text {th }} 2019$

\section{INTRODUCTION}

The ability to think critically is very important in today's modern life. Everyone must have good critical thinking skills in all fields in the environment around and outside their environment. Because critical thinking is reasoned and reflective thinking by emphasizing decision making about what to believe or do. In other words, decision making is taken after reflection and evaluation on what is believed (Ennis, 2002). So that when getting the information that must be received, it is important information and information that is not important for everyone. With the ability to think critically in good individuals, these individuals will be able to distinguish, develop, remember and analyze between important information and insignificant information. Therefore, in order to be able to adapt to this modern life, one must instill the ability to think critically on oneself since children in elementary school. Education as a major milestone for improving the quality of human resources, in its role is very important for nation building. The implementation of education in Indonesia is regulated in a system called the curriculum. At the moment the 2013 curriculum is used, with the aim that students can achieve essential competency indicators, namely affective (attitudes and values), cognitive (intellectual potential), and psychomotor (ability to act in learning experiences). For that the implementation of good and true education is the success of a curriculum achieved. Good and correct education is applied at a level of educational institutions determined by the quality of the teaching process applied by the teacher. The teaching process carried out by the teacher in a good and correct learning, through thematic-integration methods. The teacher must be able to integrate the various competencies of each subject into the theme. Teachers in conveying knowledge in the learning process must be good and right, so that the knowledge received by students can achieve competency indicators that are essential especially in learning natural sciences subjects.

Natural Science (IPA) is a study of natural conditions and events systematically through observational and experimental activities through facts, concepts, processes of discovery and attitudes. So that knowledge from the results of human activities obtained by using scientific steps in the form of scientific methods and obtained from the results of experiments or observations that are general in nature so that it will continue to be refined (Muslicha, 2006). With natural science education students will be guided to think critically, solve problems, and 
make decisions that can improve the quality of life towards a scientifically learned society. In the subjects of Ipa Education (IPA) have various materials, especially alternative energy materials. Alternative energy is energy that is used or used to replace conventional energy or materials. Alternative energy has benefits for humans in everyday life. For example hydroelectric power plants, wind power plants and solar radiation energy which is heat energy. Therefore, learning alternative energy materials is taught in elementary schools so that students can take advantage of existing energy.

With the importance of the material that must be mastered by students, it is necessary to have a learning model made by the instructor in the learning process. The achievement of a learning goal is influenced by a learning model. So that the learning process that takes place is not monotonous, does not seem rigid, and less attractive. The more diverse learning models used by teachers, the delivery of messages in the form of learning materials will be more easily accepted by students. For natural science subjects there are many learning models used by teachers, namely learning models that focus on teachers and learning models that focus on students. Examples of learning models that are focused on students are inquiry learning models. The inquiry learning model is a framework of learning activities that involve maximally all students' abilities to search and investigate systematically, critically, and logically. So that students can find their own knowledge, attitudes and skills as a form of behavior change (Hanafiah and Suhana, 2014: 77).

The inquiry learning model emphasizes maximum student activity to find and find. Which has orientation steps, formulates problems, composes hypotheses, collects data, tests hypotheses and conclusions. Therefore, that inquiry learning model is centered on students so they can train the skills possessed by students, the most important is the ability of critical thinking skills. With students having good critical thinking skills, they will receive knowledge from the instructor well. Critical thinking is a disciplinary process that is intellectually active and skilled at conceptualizing, applying, analyzing, synthesizing, and evaluating information collected from results by observation, experience, reflection, reasoning, or communication, as a guide to trust and action. Critical thinking skills in students are very important to develop. It is intended that later when students are faced with a problem, students can solve the problem. In addition, students can select various information obtained, and can determine what is right and what is wrong (Tawil \& Liliasari, 2013).

From the results of the observation activities in the learning process activities in Dukuhtunggal Elementary School from class I to class VI, it is known that students find it difficult to accept material so that interest in asking about the material taught by the teacher is lacking. This is the same as what was said by the teacher of each class from class I to class VI through interview activities that students are lacking in asking questions about the material taught by the teacher. And it is proven by the test of critical thinking skills with the C4-C6 cognitive domain and the lowest 30 and the highest 60 results. Therefore, by referring to the new version of Bloom's Cognitive Domain in David R. Krathwohl, cognitive shutter is measured using the C1-C6 problem. , But to measure critical thinking skills (Higher Order Thinking Skills) students use the C4-C6 cognitive domain. Based on interviews with fourth grade teachers, he experienced difficulties in delivering alternative energy material to natural science subjects to students. Because in delivering alternative energy material, more use of the lecture method. So that with the advantages of the inquiry learning model that has been put forward by some experts who emphasize students to investigate an existing problem and find information that is in reality. In the end students make a good conclusion or decision through critical thinking and experience. With the realm of C4-C6 knowledge capability possessed by each student as a benchmark for critical thinking skills, it is very appropriate to overcome the effective learning process for fourth grade students of natural science subjects in alternative energy materials at Dukuhtunggal Elementary School. Based on the results of the background study, critical thinking skills are instilled in students in elementary school is very important, so that students are able to master the material given by the teacher, able to make right and wrong decisions and students have extensive knowledge and are embedded in the mind with long. How to instill critical thinking skills in students using a learning model that is student-centered and encourages students to ask questions in the learning process activities. Therefore, this study was conducted to determine the effectiveness of the use of inquiry learning models in natural science critical thinking skills in alternative energy materials.

\section{METHOD}

This type of research uses experimental research which is a quantitative study using the experimental method of Pre-experimental Designs (One Pretest-Posttest Design Group). Measured by doing a pretest (O1) to find out the initial condition, then treated using the inquiry learning model in the learning process $(\mathrm{X})$, then posttest $(\mathrm{O} 2)$ was performed to determine the difference in results before being treated with already given treatment.

The location of the study was carried out in Dukuhtunggal Elementary School, Bangsal Mojokerto Subdistrict, with a sample of 30 students in class IV. The sampling technique uses Random Sampling because the taking of sample members is done randomly regardless of the strata in the population. The research instrument contained four assessment instruments, namely the test sheet (pretest and posttest), observation sheet, student response sheet, and student activity sheet. There are four techniques in collecting data, namely test techniques, 
observation techniques, student response sheets, and student activity sheets. Data analysis techniques in this research are: Effectiveness T-Test test aims to find out how effective or ineffective after treatment. The effectiveness of the t-test is carried out after conducting research and getting the posttest results using the formula:

$t_{\text {hitung }}=\frac{M d}{\sqrt{\frac{\Sigma X^{2} d}{N(N-1)}}}$

Information:

$$
\sqrt{N}
$$

$\mathrm{Md}=$ mean of deviation (d) between posttest and pretest.

$\mathrm{Xd}=$ difference in deviation with mean deviation.

$\mathrm{N}=$ number of subjects

$\mathrm{Df}=$ or $\mathrm{db}$ is $\mathrm{N}-1$

To determine the mean:

$M d=\frac{\Sigma d}{N}$

To determine the sum of squares of deviation:

$\Sigma X^{2} d=\Sigma d^{2}-\frac{(\Sigma d)^{2}}{N}$

The Response Analysis of Students is analyzed by percentage using the following formula:

$P=\frac{F}{N} \times 100 \%$

Information:

$\mathrm{P}=$ percentage answer

$\mathrm{F}=$ frequency

$\mathrm{N}=$ Number of respondents

The percentage results are interpreted in the table as follows:

Table 1. Percentage of Criteria

\begin{tabular}{ll}
\hline Percentage & Respondents \\
\hline $81 \%-100 \%$ & Very good \\
$61 \%-80 \%$ & Good \\
$41 \%-60 \%$ & Pretty good \\
$21 \%-40 \%$ & Bad \\
$0-20 \%$ & Very bad \\
\hline
\end{tabular}

(Sugiyono, 2016:139)

\section{DISCUSSION AND SUGGESTIONS}

The study was conducted on the 10th, 11th, 12th October 2018 at Dukuhtunggal Glagah Elementary School Lamongan Jawatimur Indonesia. But before conducting the research, the researchers validated the questions first, which was held on October 9, 2018 at Purwojati II Elementary School. The results of the study are as follows: To find out the data from the results of critical thinking skills, the researcher used a test in the form of 10 questions which contained 5 aspects of critical thinking skills (Interpreting, Explaining, Analyzing, Concluding, and Combining). The way to obtain the results of critical thinking results of the researchers used the pretest and posttest tests. The pretest test is given before the treatment using inquiry learning model in the learning process, while the posttest test is given at the end of the learning that has been treated by using the inquiry learning model in the learning process. The results of the grade IV pretest values above can be seen that the average pretest results are 61.3. So that grade IV students have not been able to think critically well. After obtaining the pretest test data then get the results of the posttest test. From the results of the class IV posttest values above, it can be seen that the average posttest or final test result is 77.73 . The results of the posttest can be categorized as having a good increase in value. Can be interpreted by doing treatment or treatment using inquiry learning models at the time of the natural science learning process alternative energy materials can make students think critically with good interpretasi. It is also proven by using the effectiveness $\mathrm{T}$ test as follows: 
Table 2. Test Result of Ttest Effectiveness

\begin{tabular}{|c|c|c|c|c|}
\hline No & Pretest & Posttest & D & $d^{2}$ \\
\hline 1 & 65 & 70 & 5 & 25 \\
\hline 2 & 60 & 70 & 10 & 100 \\
\hline 3 & 70 & 70 & 0 & 0 \\
\hline 4 & 70 & 90 & 20 & 400 \\
\hline 5 & 60 & 80 & 20 & 400 \\
\hline 6 & 70 & 90 & 20 & 400 \\
\hline 7 & 65 & 70 & 5 & 25 \\
\hline 8 & 65 & 80 & 15 & 225 \\
\hline 9 & 70 & 80 & 10 & 100 \\
\hline 10 & 60 & 75 & 15 & 225 \\
\hline 11 & 50 & 70 & 20 & 400 \\
\hline 12 & 65 & 75 & 5 & 25 \\
\hline 13 & 70 & 70 & 0 & 0 \\
\hline 14 & 70 & 70 & 0 & 0 \\
\hline 15 & 60 & 90 & 30 & 900 \\
\hline 16 & 65 & 80 & 15 & 225 \\
\hline 17 & 70 & 90 & 20 & 400 \\
\hline 18 & 70 & 70 & 0 & 0 \\
\hline 19 & 55 & 70 & 15 & 225 \\
\hline 20 & 60 & 80 & 20 & 400 \\
\hline 21 & 50 & 70 & 20 & 400 \\
\hline 22 & 60 & 80 & 20 & 400 \\
\hline 23 & 50 & 75 & 25 & 625 \\
\hline 24 & 65 & 85 & 20 & 400 \\
\hline 25 & 60 & 75 & 15 & 225 \\
\hline 26 & 60 & 85 & 25 & 625 \\
\hline 27 & 65 & 90 & 25 & 625 \\
\hline 28 & 50 & 70 & 20 & 400 \\
\hline 29 & 50 & 75 & 25 & 625 \\
\hline 30 & 40 & 70 & 30 & 900 \\
\hline Total & 1840 & 2332 & 465 & 10100 \\
\hline
\end{tabular}

Test calculation of ttest effectiveness:

Establish: $\mathrm{Md}=\frac{\Sigma d}{\mathrm{~N}}=\frac{465}{30}=15,5$

Establish:

$$
\begin{aligned}
\Sigma \mathrm{X}^{2} \mathrm{~d} & =\Sigma \mathrm{d}^{2}-\frac{(\Sigma d)^{2}}{\mathrm{~N}} \\
& =10.100-\frac{(325)^{2}}{30} \\
& =10.100-\frac{216.225}{30} \\
& =10.100-7.207,5 \\
& =2892,5
\end{aligned}
$$

Value of $\mathrm{N}=27$

$\mathrm{Db} \quad=\mathrm{N}-1$

$$
=30-1=29
$$

Value of $t_{\text {hitung }}$

$$
\begin{aligned}
t_{\text {hitung }} & =\frac{M d}{\frac{\sqrt{\sum \mathrm{x}^{2} \mathrm{~d}}}{\mathrm{~N}\left(\mathrm{~N}_{1}-1\right)}} \\
& =\frac{15,5}{\frac{\sqrt{2892,5}}{30(30-1)}}
\end{aligned}
$$




$$
\begin{aligned}
& =\frac{15,5}{\frac{\sqrt{2892,5}}{30 \times 29}} \\
& =\frac{15,5}{\sqrt{2892,5}} \\
& =\frac{15,5}{\sqrt{3,3}} \\
& =\frac{15,5}{1,186} \\
& =8,625
\end{aligned}
$$

Based on the ttest test above manually can be used to determine the significant effect of pretest-posttest with the acquisition of tcount 8.525 with a significant value of 0.05 . From this, it can be said that tcount (8.525)> t table (2.056), it can be stated that Ho is rejected and Ha is accepted, meaning that the inquiry learning model is effectively used in enhancing the ability to think critically in natural science learning alternative energy materials. The supporters to prove that the inquiry learning model is able to make students to think critically, namely the observation of the activities of students. The results of observations of student activities are when 15 minutes to 30 minutes students are able to listen and pay attention to well, for 45 minutes to 300 students are able to work

\begin{tabular}{|c|c|c|c|c|c|}
\hline \multirow{2}{*}{$\begin{array}{l}\text { Condition } \\
\text { category }\end{array}$} & \multirow[t]{2}{*}{ Question } & \multicolumn{2}{|c|}{$\begin{array}{l}\text { Amount of } \\
\text { answers }\end{array}$} & \multicolumn{2}{|c|}{$\begin{array}{l}\text { Percentage of } \\
\text { answers }\end{array}$} \\
\hline & & Yes & No & Yes & No \\
\hline \multirow{5}{*}{ Good } & $\begin{array}{l}\text { With critical thinking I can explain the meaning of } \\
\text { alternative energy. }\end{array}$ & 30 & 0 & $100 \%$ & $0 \%$ \\
\hline & $\begin{array}{l}\text { With the orientation activity I learned the purpose of } \\
\text { learning alternative energy materials }\end{array}$ & 29 & 1 & $96,6 \%$ & $3.3 \%$ \\
\hline & $\begin{array}{l}\text { With the existence of a problem I can solve it by } \\
\text { critical thinking }\end{array}$ & 22 & 8 & $73,3 \%$ & $26,6 \%$ \\
\hline & $\begin{array}{l}\text { With me looking for information, my critical } \\
\text { thinking skills have increased. }\end{array}$ & 24 & 6 & $80 \%$ & $20 \%$ \\
\hline & $\begin{array}{l}\text { I easily received material during the learning } \\
\text { process }\end{array}$ & 21 & 9 & $70 \%$ & $30 \%$ \\
\hline \multicolumn{4}{|c|}{ Average of Good Condition } & $83,98 \%$ & $15,98 \%$ \\
\hline
\end{tabular}
actively in groups and in the learning process even though there are some students who still pay attention. So that the results of student activities obtained by the active average in the learning process take place. To find out

\begin{tabular}{|c|c|c|c|c|c|}
\hline \multirow[t]{2}{*}{$\begin{array}{l}\text { Condition } \\
\text { category }\end{array}$} & \multirow[t]{2}{*}{ Question } & \multicolumn{2}{|c|}{$\begin{array}{c}\text { Amount of } \\
\text { answers }\end{array}$} & \multicolumn{2}{|c|}{$\begin{array}{c}\begin{array}{c}\text { Percentage of } \\
\text { answers }\end{array} \\
\end{array}$} \\
\hline & & Yes & No & Yes & No \\
\hline \multirow{5}{*}{ Not good } & I can conclude a problem well & 12 & 18 & $40 \%$ & $60 \%$ \\
\hline & $\begin{array}{l}\text { I receive information about material } \\
\text { easily. }\end{array}$ & 5 & 25 & $16,6 \%$ & $83,3 \%$ \\
\hline & I became bolder in asking about material. & 3 & 27 & $10 \%$ & $90 \%$ \\
\hline & I have difficulty receiving material. & 4 & 26 & $13,3 \%$ & $86,6 \%$ \\
\hline & $\begin{array}{l}\text { I became more active in the learning } \\
\text { process }\end{array}$ & 0 & 30 & $0 \%$ & $100 \%$ \\
\hline \multicolumn{4}{|c|}{ Average of not good condition } & $15,98 \%$ & $83,9 \%$ \\
\hline
\end{tabular}
the success of the inquiry learning model is evidenced by the students' response sheet. The response results of students as follows:

Table 3. Results of responses of Good Category Students

Table 4. Continued Response Results of the Poor Class Students

Getting the results in the statement of the good condition category and getting the final score of $83.98 \%$. From these results it can be seen that students respond well to today's learning with very good interpretation. The students' response sheets were distributed to all fourth grade students of SDN Dukuhtunggal Glagah Lamongan Jawatimur Indonesia. And supported by a review sheet of observations that were assessed by 2 people, namely, homeroom IV SDN Dukuhtunggal and colleagues. This is the result of the observation assessment sheet that the percentage of implementation of alternative energy learning using the inquiry model is $100 \%$. The value of achievement resulting from alternative energy learning is $96.739 \%$. This acquisition can be categorized as very good. 


\section{Discussion}

The study was entitled the effectiveness of inquiry learning models on critical thinking skills of fourth grade students in alternative energy material in elementary schools which aims to determine the results of students' critical thinking skills by using the incuri learning model in the learning process in science subjects with alternative energy materials. The inquiry learning model has steps in learning, namely: orientation, formulating problems, composing hypotheses, collecting data, testing hypotheses and conclusions. The learning process carried out by researchers is as follows:

1. Orientation: The teacher informs the material "Alternative Energy", question and answer about the types of energy used as alternative energy. Explain the meaning of alternative energy.

2. Formulate the problem: Questions and answers about the benefits of water energy as alternative energy. How to use water energy as a hydropower plant. What happens if the flow of water with a little volume and large volume.

3. Arrange hypotheses: Students answer these questions with the knowledge they have.

4. Collecting data: Students make simple waterwheels, by reading alternative energy materials.

5. Test the hypothesis: Learners experiment with waterwheels which are poured in small volumes of large volumes of water.

6. Conclusion: Students conclude the results of data collection and hypothesis testing into one about the occurrence of waterwheel if given a different volume.

With the inquiry learning model that uses the above steps students can have good critical thinking skills in natural science learning. To find out students can think critically well researchers use the test as a benchmark. From the results of the pretest and posttest test consisting of each of the 10 questions and containing 5 aspects of critical thinking skills (Analyzing, Explaining, Summing up, Interpreting, and Combining) fourth grade students get an average pretest value of 61.3, after that is given treatment using inquiry model in learning and getting posttest mean value 77.73 . It is evident from the increase in the average value obtained by students can be said to be able to think critically very well and can also be proven by increasing the value of each student. Students in the learning process are also active in asking questions with friends and with the teacher. This research is also proven by the calculation of the $t_{\text {test }}$ test in the calculation carried out manually with the provisions $t_{\text {hitung }}>t_{\text {tabel }}$. T-test calculations were used to determine the significant effect of pretest-posttest with the acquisition of $t_{\text {hitung }}$ 8.525 with a significant value of 0.05 . From this it can be said $t_{\text {hitung }}(8,525)>t_{\text {tabel }}(2.056)$, it can be stated that $\mathrm{Ho}$ is rejected and $\mathrm{Ha}$ is accepted meaning that the inquiry learning model is effectively used in improving critical thinking skills in alternative energy learning natural science material.

In the learning process Students feel happy at the time of learning because there is a simple experiment in the form of a water mill. Students are also required to make their own groups in a simple waterwheel experiment and conduct experiments in groups. To find out that students like and are interested in learning conducted by researchers, the researcher creates a student response sheet filled in by all students at the end of learning. The results of the response of students get a final score of $83.98 \%$. From these results it can be seen that students respond well to today's learning with very good interpretation. As explained by (Wisudawati, 2017: 47) That learning model is a conceptual framework that describes procedures systematically in organizing learning practices to achieve effective learning goals. This statement is supported by the theory put forward by (HanafiahxdanxSuhana, 2014: 77) that the inquiry learning model is an order of learning activities from the beginning to the end which involves the full ability of students to be able to search and investigate systematically, critically, logically and analyzed good, so that students can find their own knowledge, attitudes and skills as a manifestation of behavior change. By treating using inquiry learning models, students demonstrate their ability to think critically with the knowledge possessed by each student.

From data analysis and discussion of inquiry learning models make students to think hard in finding a problem and answer a problem by being encouraged by critical thinking skills when collecting as much information as possible. Students are also able to be active in solving a problem that must be answered. With learning using the inquiry model students can receive knowledge well and be embedded long in the minds of students. Using inquiry learning students respond well to the learning process takes place. It was concluded that the inquiry learning model was effective in making students think critically about fourth grade students in elementary schools.

\section{Conclusion}

The inquiry learning model is effective for improving students' critical thinking skills in science learning. This is evidenced by the results of the t-test obtained by thitung (8.525)> ttable (2.056) and the average value of students' critical thinking tests increased from the average value of pretest 61.3 after receiving treatment posttest 77 average value, 73. The inquiry learning model also makes students active in science learning. Using the inquiry model students respond well to natural science learning. This is evidenced by the response sheet of students who get a percentage of $83.9 \%$. In the learning process using inquiry learning models are categorized 
very well in the implementation of science learning alternative energy materials and make students think critically by getting a percentage of $100 \%$ while the value of achievement generated from learning uses the inquiry model that is 96,739 . In the learning process activities students feel happy, unsaturated, orderly, active and not ashamed in asking the teacher or the friend or friend.

\section{References}

Arikunto, Suharsimi. (2010). Prosedur Penelitian Suatu Pendekatan Praktik. Rineka Cipta.

Azizah, dkk. (2016). Pengaruh Model Pembelajaran Inkuiri Terbimbing Terhadap Kemampuan Berpikir Kritis Siswa Pada Materi Energi Bunyi.

Az-Zahra, Zaskia. (2017). Pembelajaran Keterampilan Berpikir Kritis Siswa di SD Negeri Percobaan 2 Yogyakarta.

Fisher, Alec. (2009). Berpikir kritis: sebuah pengantar. Erlangga

Hanafiah, nanang. M.Pd, dkk. (2014). Konsep Strategi Pembelajaran. Bandung: Rafika Aditama.

Julianto, dkk. (2017). Model pembelajaran terintegrasi. Zifatama Jawara.

Julianto, dkk. (2010). Kajian Teori dan Implementasi Model Pembelajaran Terpadu Dalam Pembelajaran di Kelas. Unesa University Pres.

Muakhirin, Binti. (2014). Peningkatan Hasil Belajar IPA Melalui Pendekatan Pembelajaran Inkuiri Pada Siswa SD.

Muh Tawil \& Liliasari. (2013). Berpikir Kompleks dan Implementasinya dalam Pembelajaran IPA. Makassar: Badan Penerbit Universitas Negeri Makassar.

Ratnasari. (2016). Keefektifan Model Guided inquiry Dalam Pembelajaran IPA Ditinjau Dari Keterampilan Berpikir Kritis Dan Generik Sains Peserta Didik Di SMP NEGERI 4 WATES.

Sugiyono. (2016). Metodologi Penelitian Kuantitatif, Kualitatif, dan R\&D. Bandung, Alfabeta.

Wijayanti, Indri, dkk. (2015). Analisis Kemampuan Berpikir Kritis Siswa Kelas V Dalam Pembelajaran IPA di 3 SD Gugus X Kecamatan Buleleng.

Winarsunu, Tulus. (2015). Statistik Dalam Penelitian Psikologi dan Pendidikan. Malang. Uneversitas Muhammadiyah Malang.

Wisudawati. (2017). Metodologi Pembelajaran IPA. Bumi Aksara. 